\title{
A közép-európai régió nagyvárosainak gazdaságirányító szerepe
}

\section{The role of cities in Central Europe as leaders of the economy}

\author{
CSOMÓS GYÖRGY
}

\section{Bevezetés}

A városokkal foglalkozó társadalomtudományi kutatások egyik meghatározó irányzata a városok rangsorolása és csoportosítása különböző szempontok alapján. Beaverstock et al. (1999) szerint a rangsorolások két eltérő megközelítésen alapulnak: a funkcionális megközelítés a nagyvárosokat nem önálló egységekként vizsgálja, hanem egy átfogó társadalmi-gazdasági rendszer részeként, ezzel szemben a demográfiai megközelítés alapvetően a nagyvárosok méretét tekinti meghatározó paraméternek. A szakirodalom a funkcionális megközelítés alapján rangsorolt városokat általában világvárosoknak (world city) vagy globális városoknak (global city) nevezi, a demográfiai megközelítés alapján rangsorolt városokat pedig megavárosoknak (mega-city). A két típus között jelentős kontraszt figyelhető meg. Egy példával kifejtve: a több mint 13 millió fős népességgel rendelkező Karacsi (Pakisztán) nyilvánvalóan megavárosnak számít, de nem világvárosnak, ezzel szemben a kevesebb mint 700 ezer fős népességü Frankfurt a világ egyik meghatározó pénzügyi központja, világvárosnak számít, de nem megavárosnak (Sassen 1991). Az európai városok közül mindössze négy-öt tekinthető megavárosnak, elsősorban a hozzávetőleg 10 milliós népességgel rendelkező Párizs, London, Moszkva és Isztambul. A közép-európai országok városaira nem lehet a megaváros definíciót alkalmazni - még a németországi városokra sem -, ugyanakkor a régió több városa is a világvárosok különböző csoportjába tartozik (Beaverstock et al. 1999). A szakirodalom természetesen meglehetősen eltérő jellemzők alapján definiálja a világvárosokat, szinte szerzőnként változik a kategorizálás. Az elemzésem szempontjából lényegesnek tartom tisztázni a világváros és globális város fogalmakat, a definíciók alkalmazási területét.

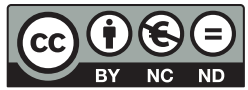


A szerzők jelentős része ugyanakkor csak érintőlegesen említi meg a kelet-közép-európai városokat. Friedmann (1995), Taylor (2004) és Sassen (2006) szerint a visegrádi országok fővárosai a Kelet-Közép-Európában üzleti tevékenységet folytató nyugati (például németországi és ausztriai) cégek legfontosabb cégközpontvárosai, úgynevezett gateway-városok. A munkák egy részéből az a következtetés vonható le, hogy a térség nagyvárosai - kiemelten Budapest, Prága és Varsó - nem rendelkeznek megfelelő gazdasági súllyal, önálló gazdaságirányító szerepük elhanyagolgató.

Jelen tanulmányban a közép-európai országok (Ausztria, Csehország, Lengyelország, Magyarország, Németország és Szlovákia) nagyvárosainak néhány jellemző gazdasági paraméterét hasonlítom össze. Arra a kérdésre keresem a választ, hogy melyek a regionális gazdaságirányítás meghatározó városai, és ebben a gazdasági rendszerben milyen szerepet töltenek be a visegrádi országok nagyvárosai.

\section{A közép-európai régió nagyvárosainak pozíciója a világvárosok között}

A világváros-definíciót Patrick Geddes (1915) vezette be a múlt század elején, majd a meghatározás többek között Hall (1966), Hymer (1972) és Heenan (1977) munkáiban teljesedett ki. A 20. század második felében a fejlett világ gazdasági növekedésével párhuzamosan robbanásszerüen növekedett a multinacionális vállalatok (MNC) száma is, gazdaságirányító szerepük pedig az egész világra kiterjedt. A városokkal foglalkozó kutatások ebben az időszakban alapvetően az MNC-k központjainak száma alapján definiálták a világvárosokat. Hall (1966) és Hymer (1972) munkáiból azonban az a következtetés is levonható, hogy a gazdaság irányítását reprezentáló MNC-k a kormányzati döntéshozatal központjaival szorosan együttműködtek. Ezek kölcsönhatása különösen Európában - a fővárosok (London, Párizs, Moszkva) dinamikus növekedését eredményezte. Az egyetlen jelentősebb kivétel Németország volt, ahol a politikai okok miatt megosztott Berlinnel szemben a tradicionális ipari terület, a Ruhr-vidék töltötte be a gazdaságirányító szerepet. Többek között az MNC-k hiánya miatt a kelet-közép-európai országok nagyvárosai - természetesen Németország és Ausztria kivételével - ezekben a munkákban még nem szerepeltek. Az egykori szocialista országok nagyvárosai közül Hall (1966) szerint csak Moszkva volt világvárosnak nevezhető, de a nyugati nagyvárosokkal szemben nem a gazdasági funkciói, hanem politikai súlya miatt.

A politikai rendszerváltozást követően a kelet-közép-európai országok gazdasági rendszere jelentősen megváltozott, átalakult. A piacgazdaságra történt átállás és a privatizáció olyan gazdasági környezetet eredményezett, amely nemcsak európai, de globális léptékben is értékelhetővé tette a régió 
nagyvárosait. Napjaink egyik meghatározó szakirodalmi műve a Saskia Sassen (1991) által jegyzett The Global City a fejlett termelést segítő szolgáltatások koncentrációja és intenzitása alapján kategorizálja a nagyvárosokat. A globális gazdaság élén - elsősorban a termelést segítő szolgáltatások jellemzőit figyelembe véve - olyan városok állnak, mint New York, London és Tokió, illetve Párizs és Frankfurt. Sassen (1991) szerint az 1990-es évek elején a kelet-középeurópai régió országainak gazdaságát a külföldi működőtőke-beruházások jellemezték, amelyek elsősorban a legfejlettebb infrastruktúrával rendelkező fóvárosokban - például Budapesten, Prágában, Varsóban - realizálódtak. Ivanička Sr. és Ivanička Jr. (2007) szerint az 1990-es években a müködésüket a régióban kiterjeszteni kívánó nyugati multinacionális vállalatok legfontosabb bázisai Prága, Varsó és Budapest voltak, aminek következtében az említett városok a regionális gazdaságirányítás központjaivá váltak. Ez utóbbi nézetet erősíti meg Enyedi György (2003) is, véleménye szerint Budapest a közép-európai régió irányításában Béccsel, Prágával és Varsóval osztozik.

A Globalization and World Cities Research Network (GaWC) 1999-ben közzétett tanulmánya világosan tükrözi a kelet-közép-európai régió nagyvárosainak megnövekedett gazdasági jelentőségét (Beaverstock et al. 1999). Négy tényező (könyvelés, reklám, banki szolgáltatás, jogi szolgáltatás) alapján készített kategorizálásuk szerint a németországi városok mellett - természetesen eltérő mértékben - Bécs, Budapest, Pozsony, Prága és Varsó rendelkezik meghatározó szereppel a régióból (1. táblázat).

A GaWC az említett tényezők alapján 122 várost vizsgált meg, és helyezett el egy 12 fokozatú skálán (GaWC-leltár). A 2. táblázatban látható a GaWCleltár eredménye, amely szerint a legtöbb közép-európai város gamma világvárosnak számít, ugyanakkor Prága, Varsó és Budapest kétségtelenül a régió meghatározó nagyvárosai közé tartoznak.

1. táblázat: A közép-európai városok sorrendje a GaWC által vizsgált kategóriákban

\begin{tabular}{|c|c|c|c|c|}
\hline Szerepkategória & $\begin{array}{c}\text { Globális } \\
\text { könyvelési } \\
\text { szolgáltatás } \\
\text { központja }\end{array}$ & $\begin{array}{c}\text { Globális reklám- } \\
\text { szolgáltatás } \\
\text { központja }\end{array}$ & $\begin{array}{l}\text { Globális banki } \\
\text { szolgáltatás } \\
\text { központja }\end{array}$ & $\begin{array}{c}\text { Globális jogi } \\
\text { szolgáltatás } \\
\text { központja }\end{array}$ \\
\hline Kiemelkedő & $\begin{array}{l}\text { Düsseldorf, } \\
\text { Frankfurt }\end{array}$ & - & Frankfurt & - \\
\hline Meghatározó & $\begin{array}{l}\text { Berlin, } \\
\text { Hamburg, } \\
\text { Köln, } \\
\text { München, } \\
\text { Stuttgart }\end{array}$ & $\begin{array}{l}\text { Bécs, } \\
\text { Düsseldorf, } \\
\text { Frankfurt, } \\
\text { Prága }\end{array}$ & $\begin{array}{l}\text { Prága, } \\
\text { Varsó }\end{array}$ & $\begin{array}{l}\text { Berlin, } \\
\text { Budapest, } \\
\text { Frankfurt, } \\
\text { Prága, } \\
\text { Varsó }\end{array}$ \\
\hline Csekély & Drezda & $\begin{array}{l}\text { Budapest, } \\
\text { Hamburg, } \\
\text { Varsó }\end{array}$ & $\begin{array}{l}\text { Bécs, } \\
\text { Budapest, } \\
\text { München, } \\
\text { Pozsony }\end{array}$ & $\begin{array}{l}\text { Düsseldorf, } \\
\text { Hamburg, } \\
\text { München, } \\
\text { Pozsony }\end{array}$ \\
\hline
\end{tabular}

Forrás: Beaverstock et al. (1999). 
2. táblázat: A közép-európai városok kategorizálása a GaWC 12 fokozatú skálája szerint

\begin{tabular}{lll}
\hline \multicolumn{1}{c}{ Alfa világváros } & \multicolumn{1}{c}{ Béta világváros } & \multicolumn{1}{c}{ Gamma világváros } \\
\hline 10: Frankfurt & - & 6: Düsseldorf, Prága \\
& & 5: Varsó \\
& & 4: Berlin, Budapest, \\
& & Hamburg, München \\
\hline $\begin{array}{l}\text { Világvárosok kialakulására } \\
\text { Pozsony, Stuttgart }\end{array}$ & bizonyítékkal szolgáló városok: Bécs, Drezda, Köln, \\
\hline Forrás: Beaverstock et al. (1999).
\end{tabular}

Forrás: Beaverstock et al. (1999).

Szükségesnek tartom hangsúlyozni, hogy a GaWC által definiált gamma világváros-kategóriába olyan városok kerületek, amelyek a négy vizsgált tényező közül legalább kettőben globális szolgáltatóközpontnak számítanak (Taylor et al. 2002a). A kategóriába tartozó 35 város között a 2. táblázatban látható közép-európai városokon kívül - többek között - olyan globális jelentőségű metropoliszok vannak, mint Buenos Aires, Houston, Miami, Montreal, Oszaka, Peking, Róma, Taipei, Sanghaj és Washington.

A GaWC elemzését azért tartom lényegesnek és meghatározó jelentőségünek, mert a közép-európai városokat objektív szempontok szerint rangsorolja.

Az eddigiekben bemutatott források alapvetően globális szinten rangsorolták a régió nagyvárosait, ugyanakkor - a GaWC kivételével - kevéssé hangsúlyozva a városok relatív erőviszonyait. A következő fejezetben a közép-európai térség nagyvárosainak sorrendjét kívánom meghatározni, elsősorban gazdasági erejük szempontjából, számszerüsíthető paraméterek alapján.

\section{A nagyvárosok szerepe a regionális gazdaságirányításban}

A nagyvárosok rangsorolása sokszor meglehetősen szubjektív szempontok alapján történik, elsősorban azért, mert a városok meglehetősen kevés összehasonlítható adattal rendelkeznek (Taylor et al. 2002b). Az általánosan mért jellemző a népesség, amely a városokat a demográfiai megközelítés szerint rangsorolja, azonban a gazdasági jellemzők összehasonlítására nem alkalmas. Turok és Mykhnenko (2007) szerint a népességszámnál sokkal fontosabb mutató a népességszám változása, amely lényeges következménye, ugyanakkor befolyásoló tényezője is a városok gazdasági kondícióinak. Elemzésükben 310 európai város népességszám-változását vizsgálták meg 1960 és 2005 között, és kilenc "pályát” határoztak meg. Véleményük szerint a közép-európai régió legtöbb városa közepes időtávon hanyatló pályán mozog, ami az 1970-es, 1980-as évek növekedése után jelentős visszaesést mutat. Mindez nyilvánvalóan az 1990-es évek elejétől bekövetkezett társadalmi-gazdasági változások negatív hatásait tükrözi. Speciális a helyzete Budapestnek, amely hosszú távon 
hanyatló pályán halad, és többnyire csökkenő szerepkörü nyugat-európai iparvárosokkal (például Lensszel, Le Havreral, Saarbrückennel, Magdeburggal, a Ruhr-vidékkel) került egy csoportba. Mulligan és Crampton (2005) ugyanakkor kifejti, hogy a városok erőteljes népességszám-növekedése napjainkban elsősorban a fejlődő országokat érinti, a közép-európai régióban a népességszám változása konzekvens csökkenő tendenciát mutat. A városok népességszámát és népességszám-változását a következők miatt nem tartom meghatározónak a jelen elemzés szempontjából:

- A közép-európai térség nagyvárosainak (döntően a fővárosoknak) a népességszáma 500 ezer és 2 millió fö között változik, de a városok népességszáma között kiugró eltérések nincsenek. A régió legnépesebb városa, a 3,7 millió fős népességü Berlin az egyetlen, amely a világ 100 legnépesebb városa között szerepel (UN 2008). Nemzetközi viszonylatban a régió nagyvárosai nem rendelkeznek meghatározó népességszámmal.

- A közép-európai térség nagyvárosainak alapvetően hasonló a demográfiai attitüdje, a népességszámuk döntően csökkenő tendenciával mutat (Turok - Mykhnenko 2007).

- A világvárosokra elsősorban a globális gazdasági rendszerben betöltött kiemelkedő szerepük a jellemző, és nem a méretük (Sassen 1995).

Lényeges tehát a városok gazdasági szerepét olyan közvetlen paraméterek alapján vizsgálni, amelyek - szemben a népességszámmal - egyértelműen utalnak a globális (vagy regionális) gazdaságban betöltött szerepükre. Természetesen roppant nehéz konzekvens és egységes paramétereket találni, hiszen a városok gazdasági erejének meghatározása szerzőnként eltérő szemlélet és adatok alapján történik.

- Sassen (2006) szerint napjainkban a multinacionális vállalatok (MNC) a világgazdaság szervezői, az MNC-k forgalma vagy piaci kapitalizációja alapján a cégközpontvárosok rangsorolhatók.

- A globális tőkeellenőrzés egy nagyon jellemző indikátora Musil (2009) szerint a külföldi működőtőke-beruházás (FDI), amelynek mennyisége alapján szintén létrehozható egy hierarchikus rendszer.

- Smith és Timberlake (2002) a világvárosok közötti légi utasforgalom alapján állítanak fel sorrendet, amely - véleményük szerint - világosan tükrözi az egymással összekapcsolt városoknak a gazdasági rendszerben betöltött szerepét.

- Taylor (2004) 315 város kapcsolódásának volumenét vizsgálta meg a globális hálózathoz, a könyvelésben, reklámban, banki és pénzügyi tevékenységben érdekelt tíz különböző cég szolgáltatásának értéke alapján, és állított fel sorrendet.

Véleményem szerint a közép-európai régió városainak viszonylagos sorrendjét meg lehet vizsgálni a felsorolt források segítésével, kiegészítve azokat a nemzetközi szervezetek adataival. 


\section{A városok rangsora a vásárlőeró-paritáson mért GDP és a nominális GDP alapján}

A gazdasági teljesítmény kifejezésének legegyszerübb módszere a bruttó hazai termék, amely nemzetgazdaságok esetében viszonylag pontos összehasonlításra ad lehetőséget, városok esetében azonban csak becslések léteznek. A PricewaterhouseCoopers (PwhC) által 2009-ben készített elemzés a világ 151 nagyvárosának a vásárlóerő-paritáson mért bruttó hazai termékét (GDP PPS) tartalmazza. A 2008-as adatok becslések, a 2025-re megadottak pedig az ENSZ népességszámbecslése alapján készített előrejelzések. A 3. táblázatban látható, hogy a közép-európai térség legnagyobb összesített GDP PPS értékkel rendelkező városa nem egy németországi város, hanem Ausztria fővárosa, Bécs. A rangsorban a második helyen álló, 3,4 milliós népességgel rendelkező Berlin GDP PPS értéke mindössze kétharmada a pontosan feleakkora népességgel rendelkező Bécsnek.

A PwhC szerint a visegrádi országok legnagyobb gazdasági teljesítménnyel rendelkező városa Varsó, amely a GDP PPS értéket figyelembe véve megelőzi Münchent. Bár Varsó 2008-ban még Hamburg mögött állt a negyedik helyen, a 3. táblázatban látható, hogy 2025-re a közép-európai térség harmadik legjelentősebb gazdasági szereplojévé válik. A hosszú távú prognózisok alapján ugyanakkor megállapítható, hogy az összesített GDP PPS abszolút növekedése ellenére 2025-re a régió valamennyi városa veszít 2008-as pozíciójából (Budapest például 16 hellyel kerül hátrébb a rangsorban, miközben GDP PPS értéke másfélszeresére növekedik).

A PwhC elemzését egy saját elemzéssel egészítettem ki, amely szintén a GDP-értékekre vonatkozik, azonban nem a vásárlóerő-paritáson mért, hanem a nominális értékeket tartalmazza. A rangsort az Urban Audit adatbázisában

3. táblázat: A közép-európai térség városainak becsült GDP PPS értéke 2008-ban és 2025-ben

\begin{tabular}{|c|c|c|c|c|c|}
\hline $\begin{array}{l}\text { Sorrend } \\
\text { (2008) }\end{array}$ & $\begin{array}{c}\text { A városok } \\
\text { rangsora a } \\
\text { becsült GDP } \\
\text { PPS alapján } \\
\text { (2008) }\end{array}$ & $\begin{array}{c}\text { Becsült GDP } \\
\text { PPS 2008-ban, } \\
\text { milliárd USD }\end{array}$ & $\begin{array}{c}\text { Sorrend } \\
\text { (2025) }\end{array}$ & $\begin{array}{c}\text { A városok } \\
\text { rangsora a } \\
\text { becsült GDP } \\
\text { PPS alapján } \\
\text { (2025) }\end{array}$ & $\begin{array}{c}\text { Becsült GDP } \\
\text { PPS 2025-ben, } \\
\text { milliárd USD } \\
\text { 2008-as } \\
\text { árfolyamon }\end{array}$ \\
\hline 50. & Bécs & 122 & 67. & Bécs & 175 \\
\hline 69. & Berlin & 95 & 86. & Berlin & 117 \\
\hline 79. & Hamburg & 74 & 94. & Varsó & 107 \\
\hline 85. & Varsó & 68 & 108. & Hamburg & 93 \\
\hline 89. & München & 64 & 115. & München & 81 \\
\hline 100. & Budapest & 53 & 116. & Budapest & 80 \\
\hline 106. & Prága & 49 & 121. & Prága & 75 \\
\hline 144. & Krakkó & 13 & 150. & Krakkó & 21 \\
\hline
\end{tabular}

Forrás: PricewaterhouseCoopers, 2009. 
szereplő egy före jutó nominális GDP-értékek alapján határoztam meg, figyelembe véve a városok népességszámát 2010-ben, és az Eurostat által közzétett nemzetgazdasági GDP-érték változását. A 4. táblázatban látható, hogy a térség legnagyobb nominális GDP-értékével rendelkező városa Berlin, amelyet két németországi város, Hamburg és München követ. Ebben a rangsorban Bécs csak a negyedik helyen szerepel. A visegrádi országok fóvárosai - Pozsony kivételével - megközelítőleg hasonló nominális GDP-vel rendelkeznek, sorrendjük pedig megegyezik a PwhC által közzétett sorrenddel.

A nemzetgazdasági tevékenység decentralizációját világosan tükrözik az első és második legnagyobb GDP-vel rendelkező városok közötti arányok. Németország esetében Berlin GDP-je gyakorlatilag megegyezik a második helyen álló Hamburg GDP-jével (bár Berlin és Hamburg népességszáma között jelentős az eltérés), sőt a harmadik helyen álló München értékénél is csak alig 1,14-szer nagyobb. Ezzel szemben Varsó GDP-je 4,1-szer nagyobb, mint a második város, Krakkó értéke, Prága GDP-je 4,7-szer nagyobb, mint a második helyezett Brno értéke, Budapest GDP-je pedig 22,6-szer nagyobb a listán nem szereplő, de Magyarországon a második helyen álló Debrecen GDP-jénél. Németország kivételével a közép-európai országok erősen főváros-centralizált gazdasági szerkezetet mutatnak, ami közismert tény, de a GDP-értékek ezt meg is erősítik.

A GDP-adatok alapján számos következetés levonható, ugyanakkor a különböző becslések (a nemzetgazdasági GDP városi szintű lebontására, a népességszám változására, a városok agglomerációs területének meghatározására) túlságosan sok bizonytalansági tényezőt tartalmaznak. Az elemzésből kiderül,

4. táblázat: A közép-európai térség városainak becsült nominális GDP-értéke 2010-ben

\begin{tabular}{ccc|ccc}
\hline $\begin{array}{c}\text { Sorrend } \\
\text { (2010) }\end{array}$ & $\begin{array}{c}\text { A városok } \\
\text { rangsora a } \\
\text { becsült } \\
\text { nominális GDP } \\
\text { alapján (2010) }\end{array}$ & $\begin{array}{c}\text { Becsült } \\
\text { nominális GDP } \\
\text { 2010-ben, } \\
\text { milliárd euró }\end{array}$ & $\begin{array}{c}\text { Sorrend } \\
(2010)\end{array}$ & $\begin{array}{c}\text { A városok } \\
\text { rangsora a } \\
\text { becsült } \\
\text { nominális GDP } \\
\text { alapján (2010) }\end{array}$ & $\begin{array}{c}\text { Becsült } \\
\text { nominális GDP } \\
\text { 2010-ben, } \\
\text { milliárd euró }\end{array}$ \\
\hline 1. & Berlin & 86,41 & 14. & Bréma & 22,07 \\
2. & Hamburg & 86,16 & 15. & Essen & 20,45 \\
3. & München & 75,37 & 29. & Pozsony & 8,27 \\
4. & Bécs & 69,62 & 30. & Krakkó & 8,17 \\
5. & Frankfurt & 51,44 & 31. & Poznan & 8,07 \\
6. & Köln & 43,22 & 35. & Lódz & 6,33 \\
7. & Düsseldorf & 39,93 & 37. & Wroclaw & 6,27 \\
8. & Stuttgart & 35,97 & 42. & Brno & 5,40 \\
9. & Varsó & 33,45 & 43. & Gdansk & 4,60 \\
10. & Budapest & 29,35 & 46. & Ostrava & 3,66 \\
11. & Prága & 25,56 & 48. & Szczecin & 2,80 \\
12. & Hannover & 22,95 & 49. & Katowice & 2,67 \\
13. & Nürnberg & 22,60 & 50. & Pilzen & 2,32 \\
\hline
\end{tabular}

Forrás: Eurostat Urban Audit, nemzeti statisztikai hivatalok. 
hogy a nominális és a vásárlóerő-paritáson mért GDP-adatok eltérően pozicionálják a városokat, ugyanakkor egy hosszú távú becslés egy gazdasági válság miatt érvényét is veszítheti, ahogyan az be is következett.

\section{A városok rangsora a multinacionális vállalatok paraméterei alapján}

A városok gazdasági potenciálját a becsült GDP-adatok mellett a bennük koncentrálódó multinacionális vállalatok (MNC) különböző adatai alapján is meg lehet határozni. Sassen $(1991,2006)$ szerint erre nemcsak a cégközpontok száma alkalmas, hanem többek között a cégek forgalma és piaci kapitalizációja is.

A következő elemzésben a Forbes „The Global 2000” 2010-re vonatkozó adatbázisa alapján meghatároztuk, hogy melyik városban található az adott ország legjelentősebb cégeinek központja, és azokhoz mekkora forgalom tartozik. Az 5. táblázatban látható rangsor része egy nagyobb elemzésnek, amely 450 város és 1977 multinacionális vállalat adatait tartalmazza. A 2010-hez tartozó rang azt mutatja meg, hogy az adott közép-európai város hányadik helyen szerepel a 450 várost tartalmazó listán. A GDP-adatok alapján bemutatott rangsorokkal szemben az MNC-k forgalma alapján készített rangsor jelentős eltéréseket mutat, és a németországi városok egyértelmű fölényét hangsúlyozza. Az 5. táblázat szerint a világ 12. legjelentősebb cégközpontvárosa München (434,95 milliárd USD forgalom), az itt található tíz cég forgalma több mint kétszer nagyobb Ausztria, Csehország, Magyarország és Lengyelország 21 cégének összesített forgalmánál. A visegrádi országok legnagyobb

5. táblázat: A közép-európai cégközpontvárosok rangsora az MNC-k forgalma alapján, 2010-ben

\begin{tabular}{|c|c|c|c|c|c|c|c|}
\hline Rang & $\begin{array}{l}\text { A városok rang- } \\
\text { sora az MNC-k } \\
\text { összesített forgal- } \\
\text { ma alapján }\end{array}$ & $\begin{array}{c}\text { Összesí- } \\
\text { tett } \\
\text { forga- } \\
\text { lom, mil- } \\
\text { liárd USD }\end{array}$ & $\begin{array}{c}\text { A cég- } \\
\text { köz- } \\
\text { pontok } \\
\text { száma }\end{array}$ & Rang & $\begin{array}{l}\text { A városok rang- } \\
\text { sora az MNC-k } \\
\text { összesitett forgal- } \\
\text { ma alapján }\end{array}$ & $\begin{array}{l}\text { Összesí- } \\
\text { tett } \\
\text { forga- } \\
\text { lom, mil- } \\
\text { liárd USD }\end{array}$ & $\begin{array}{l}\text { A cég- } \\
\text { köz- } \\
\text { pontok } \\
\text { száma }\end{array}$ \\
\hline \multicolumn{4}{|c|}{ Németország } & \multicolumn{4}{|c|}{ Közép-Európa Németország nélkül } \\
\hline \multicolumn{2}{|c|}{ 12. München } & 434,95 & 10 & \multicolumn{2}{|c|}{ 64. Bécs } & 112,07 & 9 \\
\hline \multicolumn{2}{|c|}{ 20. Düsseldorf } & 298,72 & 6 & \multicolumn{2}{|c|}{ 135. Budapest } & 25,47 & 2 \\
\hline \multicolumn{2}{|c|}{ 28. Stuttgart } & 231,84 & 4 & \multicolumn{2}{|c|}{ 140. Plock } & 23,70 & 1 \\
\hline & 169,47 & 3 & \multicolumn{2}{|c|}{ 180. Linz } & 16,46 & 2 \\
\hline \multicolumn{2}{|c|}{ 51. Frankfurt } & 138,59 & 6 & \multicolumn{2}{|c|}{ 212. Gdansk } & 11,92 & 2 \\
\hline \multicolumn{2}{|c|}{ 70. Essen } & 93,18 & 2 & \multicolumn{2}{|c|}{ 227. Varsó } & 10,70 & 2 \\
\hline \multicolumn{2}{|c|}{ 82. Ludwigshafen } & 72,63 & 1 & \multicolumn{2}{|c|}{ 238. Prága } & 9,44 & 1 \\
\hline \multicolumn{2}{|c|}{ 90. Hannover } & 64,23 & 3 & \multicolumn{2}{|c|}{ 317. Maria Enzersdorf } & 3,99 & 1 \\
\hline \multicolumn{2}{|c|}{ 104. Leverkusen } & 52,62 & 2 & \multirow{2}{*}{\multicolumn{2}{|c|}{ 320. Lublin }} & \multirow[t]{2}{*}{3,92} & \multirow[t]{2}{*}{1} \\
\hline 147. & Karlsruhe & 22,30 & 1 & & & & \\
\hline
\end{tabular}

Forrás: Forbes The Global 2000, Hoovers Inc. 
összesített forgalommal rendelkező városa, Budapest (25,47 milliárd USD forgalom) csak a nemzetközi rangsor 135. helyén szerepel. Szükséges ugyanakkor hangsúlyozni, hogy Magyarország és Csehország csak egy-egy várossal szerepel a rangsorban, ezzel szemben Lengyelországot négy város is képviseli: Plock, Gdansk, Varsó és Lublin.

Az MNC-k forgalma alapján bemutatott elemzés természetesen csak egy lehetséges megközelítés, azonban - a viszonylag izolált állapotot tükröző GDP-becslésekkel szemben - az MNC-k forgalma a városoknak a gazdaságirányításban betöltött szerepére is utal. Ezt egy összehasonlítással illusztrálom: a közel 14 milliós népességgel rendelkező Metropolitan Manila a PwhC (2009) szerint 149 milliárd USD GDP PPS értékkel rendelkezik, amely bármelyik közép-európai város értékénél nagyobb, miközben a Forbes „The Global 2000” (2010. évi) adatbázisában szereplő három manilai multinacionális vállalat összesített forgalma Prága egyetlen, a Forbes-adatbázisban szereplő MNC-jének a (CEZ-nek) forgalmával egyezik meg.

\section{Városok rangsora a tózsdék teljesítménye alapján}

Sassen (2006) arra hívja fel a figyelmet, hogy a világ vezető városainak meghatározó jellemzője a nagymértékű tőkekoncentráció, amelyet nemcsak a bankok reprezentálnak, hanem a tőzsdék is. A 6. táblázatban a közép-európai térség tőzsdéinek két jellemző paraméterét tüntettem fel: a tőzsdén jegyzett cégek számát és a belföldi piaci kapitalizációt. A régió legjelentősebb tőzsdéje minden tekintetben a Frankfurti Értéktőzsde, amely a piaci kapitalizáció alapján a világ 12. legnagyobb tőzsdéje. A Budapesti Értéktőzsde, a Prágai Értéktőzsde, a Varsói Értéktőzsde és a Bécsi Értéktőzsde a piaci kapitalizáció vonatkozásában messze lemaradva követi a németországi tőzsdét. Jelentős eltérések mutatkoznak a tőzsdén jegyzett cégek számának tekintetében is. Nyilvánvaló, hogy ebben a vonatkozásban is a Frankfurti Értéktőzsde áll az élen, azonban a régió többi tőzsdéjét jelentősen megelözi a Varsói Értéktőzsde. Mivel valamennyi tőzsdén döntően belföldi bejegyzésű vállalatok találhatók, a tőzsdék teljesítménye egyértelműen tükrözi a nemzetgazdaságok erőviszonyait.

\section{6. táblázat: A közép-európai régió tőzsdéinek főbb adatai 2009-ben}

\begin{tabular}{llcc}
\hline \multicolumn{1}{c}{ Város } & \multicolumn{1}{c}{ Tózsde } & $\begin{array}{c}\text { A jegyzett vállalatok } \\
\text { száma }\end{array}$ & $\begin{array}{c}\text { Belföldi piaci kapita- } \\
\text { lizáció, millió USD }\end{array}$ \\
\hline Frankfurt & Frankfurti Értéktőzsde & 783 & 1292355 \\
Varsó & Varsói Értéktőzsde & 486 & 150962 \\
Bécs & Bécsi Értéktőzsde & 115 & 114076 \\
Budapest & Budapesti Értéktőzsde & 46 & 30037 \\
Prága & Prágai Értéktőzsde & 25 & 75022 \\
\hline
\end{tabular}

Forrás: World Federation of Exchanges, Annual report and statistics, 2009. 
Szükséges ugyanakkor megjegyezni, hogy a visegrádi országok tőzsdéi meglehetősen rövid idő alatt érték el a jelenlegi teljesítményüket. A politikai és gazdasági rendszerváltozást követően az 1990-es évek elejétől indulhatott el valamennyi tőzsde, elsőként 1990-ben éppen a Budapesti Értéktőzsde. Sassen (2006) szerint az 1990-es években a visegrádi országok gyors gazdasági fellendülését alapvetően a külföldi müködőtőke-beruházások (FDI) hajtották, a belföldi cégek hozzájárulása a nemzetgazdaság teljesítményéhez viszonylag alacsony volt. Mivel a régió tőzsdéin - ahogy korábban említettem - alapvetően belföldi cégek szerepelnek, nem meglepő, hogy a belföldi piaci kapitalizáció értéke viszonylag alacsony. Többek között ez tette lehetővé, hogy a régióban terjeszkedő Bécsi Értéktőzsde többségi részesedést szerezzen a magyarországi és a csehországi tőzsdében is, utóbbiban éppen a Varsói Értéktőzsdével szemben.

A tőzsdék tulajdonosi hátterének átrendeződéséből arra lehet következtetni, hogy a közép-európai régióban Bécs mellett Varsó gazdasági irányítószerepe erősödik, miközben Budapest és Prága szerepe csökken vagy stagnál. A Frankfurti Értéktőzsde az említett városok tőzsdéihez képest más dimenziót képvisel, a piaci kapitalizáció értékének és a jegyzett cégek számának tekintetében is a globális pénzpiacok legjelentősebb központjai közé tartozik.

\section{Összefoglalás}

Az elmúlt évtizedek egyik népszerű társadalomtudományi kutatási irányzatának fókuszában a városok állnak. A kutatások elsősorban két területet érintenek: a kutatók egyrészt azt vizsgálják, hogy a fejlődő világ robbanásszerűen növekedő megavárosai milyen pozíciót foglalnak el a globális gazdaságban, másrészt továbbra is lényeges kérdés, hogy a fejlett világ nagyvárosai között milyen hierarchikus rendszer alakult ki, melyek a világgazdaság vezető városai. A közép-európai városok jelentős többsége ezekben a kutatásokban csak érintőlegesen szerepel, hiszen sem népességszámuk, sem gazdasági potenciáljuk nem kiemelkedő. Tulajdonképpen ez tükröződik az egyik legfontosabbnak nevezhető munkában is: a Globalization and World Cities Research Network 122 városra kiterjedő kutatása szerint a közép-európai országok fővárosai (eltekintve Frankfurttól) mindössze gamma világvárosnak számítanak. Az elemzésükben három tényező alapján vizsgáltuk meg a közép-európai városokat:

- a városok vásárlóerő-paritáson mért GDP-je és nominális GDP-je;

- a városokban található multinacionális vállalatok központjainak száma és azok összesített forgalma;

- a regionális tőzsdeközpontokban jegyzett vállalatok száma és a belföldi piaci kapitalizáció értéke. 
Nem meglepetés, hogy a GDP-adatok értékelése a németországi városok és Bécs fölényét mutatja, ugyanakkor a visegrádi országok közül egyértelmüen Varsó rendelkezik a legjelentősebb GDP-értékkel. A GDP-adatok ugyanakkor kevésbé utalnak a városok gazdaságirányításban betöltött szerepére, sokkal inkább egy izolált állapotot mutatnak.

Éppen ezért tartottam lényegesnek megvizsgálni a világviszonylatban is meghatározó multinacionális vállalatok területi elhelyezkedését és a cégek forgalmát (ez utóbbi világosan utal a cégeknek a gazdaságirányításban betöltött szerepére). Az eredmények azt mutatják, hogy a közép-európai térségben a németországi városok a gazdaságirányítás központjai, a visegrádi országok városai - a legnagyobb összesített forgalommal rendelkező Budapesttel együtt - csak a régió városainak középső csoportjában helyezkednek el. A multinacionális vállalatok adatainak elemzése a visegrádi országok egy lényeges sajátosságára hívja fel a figyelmet: a legtöbb cégközponttal és a legnagyobb összesített forgalommal Lengyelország rendelkezik, aminek az az oka, hogy - szemben Csehországgal és Magyarországgal - a fóváros mellett további városok is rendelkeznek regionális szinten meghatározó MNC-vel.

Végezetül a régió tőzsdéinek két jellemző paraméterét, a tőzsdén jegyzett összes vállalat számát és a belföldi piaci kapitalizációt vizsgáltam meg. A középeurópai tőzsdék csoportjából kiemelkedik a Frankfurti Értéktőzsde, amely a globális pénzpiacok meghatározó szereplője. A régió vezető tőzsdéje a Varsói Értéktőzsde, amellyel a Bécsi Értéktőzsde a magyarországi és a csehországi tőzsdék ellenőrzésének megszerzésével kívánja felvenni a versenyt. Ugyanakkor a Varsói Értéktőzsdén jegyzett vállalatok száma önmagában is több, mint a régió összes többi tőzsdéjén szerepelő cégek száma, a lengyel gazdaság erősödése pedig a belföldi piaci kapitalzáció növekedését eredményezheti.

Alapvető következtetésem szerint a közép-európai régió meghatározó városai a gazdaságirányítás vonatkozásában a németországi városok és Bécs. A visegrádi országok városai közül Budapest, Prága és Varsó jelenleg közel hasonló gazdasági teljesítménnyel rendelkezik, azonban prognosztizálható Varsó vezető szerepe, amely hosszú távon Bécs teljesítményét is elérheti.

\section{Irodalom}

Beaverstock, J. V., Taylor, P. J., Smith, R. G. (1999): A roster of world cities. Cities, 6., 445-458. Enyedi Gy. (2003): Városi világ - városfejlődés a globalizáció korában. Habilitációs Előadások, 4. Pécsi Tudományegyetem Közgazdaságtudományi Kar, Regionális Politikai és Gazdaságtani Doktori Iskola, Pécs

Friedmann, J. (1995): Where we stand: a decade of world city research. In: Knox, P. L., Taylor, P. J. (eds.): World cities in a world-system. Cambridge University Press, Cambridge, 21-47.

Geddes, P. (1915): Cities in evolution. Benn, London

Hall, P. (1966): The world cities. Heinemann, London

Heenan, D. A. (1977): Global cities of tomorrow. Harvard Business Review, 55., 79-92. 
Hymer, S. (1972): The multinational corporation and the law of uneven development. In: Bhagwati, J. (ed.): Economics and world order from the 1970s to the 1990s. Collier-MacMillan, New York, 113-140.

Ivanička, K. Sr., Ivanička, K. Jr. (2007): Regional growth dynamics in Central and Eastern Europe in the socio-economic and geographic context of a post-socialist reality. In: Stanilov, K. (ed.): The Post-Socialist City: urban form and space transformations in Central and Eastern Europe after socialism. Springer, Dordrecht, 35-52.

Mulligan, G. F., Crampton, J. P. (2005): Population growth in the world's largest cities. Cities, 5., $365-380$.

Musil, R. (2009): Global capital control and city hierarchies: an attempt to reposition Vienna in a world city network. Cities, 5., 255-265.

PwhC [PricewaterhouseCoopers] (2009): UK Economic Outlook, November 2009., http://www.pwc.com/im/en/assets/document/UK_Economic_Outlook_Nov_09.pdf Letöltve: 2011. márc. 3.

Sassen, S. (1991): The Global City: New York, London, Tokyo. Princeton University Press, Princeton

Sassen, S. (1995): On concentration and centrality in the global city. In: Knox, P. L., Taylor, P. J. (eds.): World cities in a world-system. Cambridge University Press, Cambridge, 63-78.

Sassen, S. (2006): Cities in a world economy (Third edition). Pine Forge Press, Thousand Oaks

Smith, D., Timberlake, M. (2002): Hierarchies of dominance among world cities: A network approach. In: Sassen, S. (ed.): Global networks, linked cities. Routledge, New York-London, 117-144.

Taylor, P. J., Walker, D. R. F., Beaverstock, J. V. (2002a): Firms and their global service sector. In: Sassen, S. (ed.): Global networks, linked cities. Routledge, New York-London, 93-115.

Taylor, P. J., Walker, D. R. F., Catalno, G., Hoyler, M. (2002b): Diversity and power in the world city network. Cities, 4., 231-241.

Turok, I., Mykhnenko, V. (2007): The trajectories of European cities, 1960-2005. Cities, 3., 165-182.

UN [United Nations] (2008): World Urbanization Prospects, The 2007 Revision. United Nations, New York 